\title{
PROPOSAL SKRIPSI
}

PENGARUH TEKNIK EVALUASI PRE TEST DAN POST TEST TERHADAP PENCAPAIAN ASPEK KOGNITIF PEMBELAJARAN SEJARAH SISWA KELAS XI SOSIAL SMAN 1 MARTAPURA

\section{Dosen Pengampu:}

Prof. Ersis Warmansyah Abbas, M.Pd., Dr. Syaharuddin, S.Pd, M.A, Heri Susanto, M.Pd

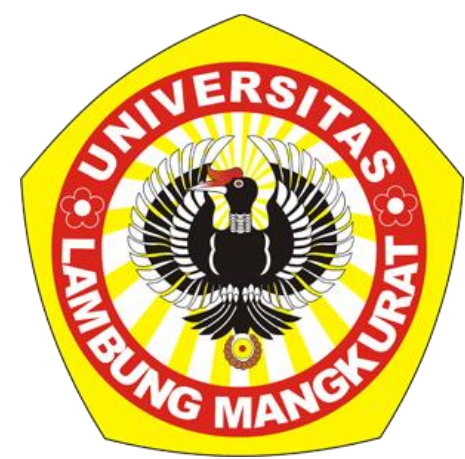

OLEH:

ANNISA

NIM. 1810111120017

PROGRAM STUDI PENDIDIKAN SEJARAH JURUSAN PENDIDIKAN ILMU PENGETAHUAN SOSIAL FAKULTAS KEGURURUAN DAN ILMU PENDIDIKAN UNVERSITAS LAMBUNG MANGKURAT 2021 


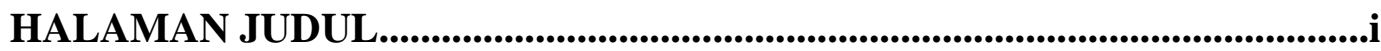

DAFTAR ISI..........................................................................................................

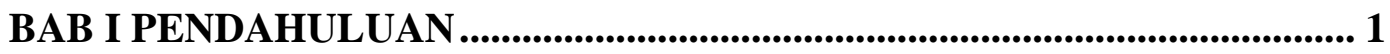

A. Latar Belakang Masalah ........................................................................ 1

C. Pembatasan Masalah.............................................................................. 5

D. Rumusan Masalah............................................................................... 5

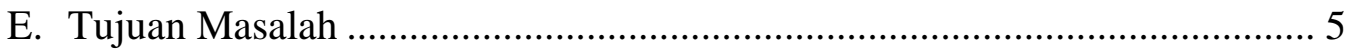

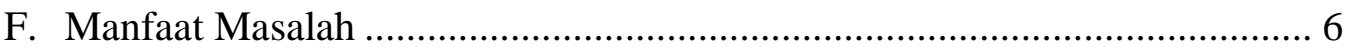

BAB II KAJIAN TEORI, KERANGKA PIKIR DAN HIPOTESIS ................ 7

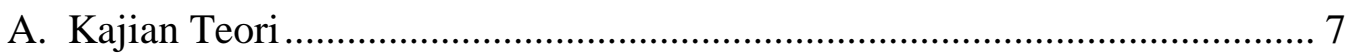

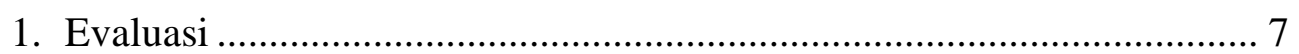

2. Pre-Test dan Post-Test....................................................................... 8

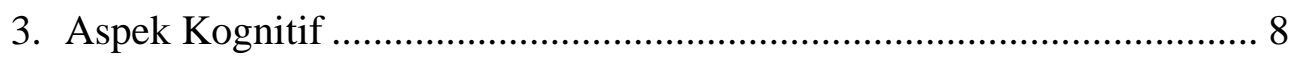

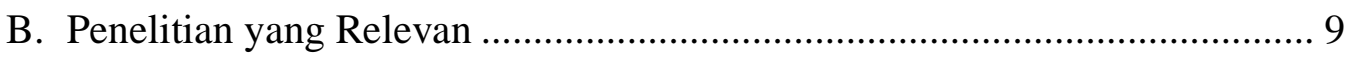

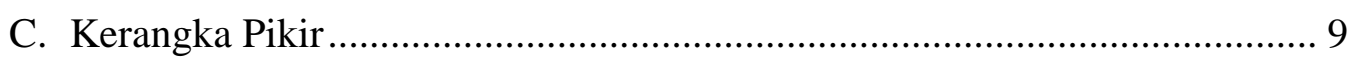

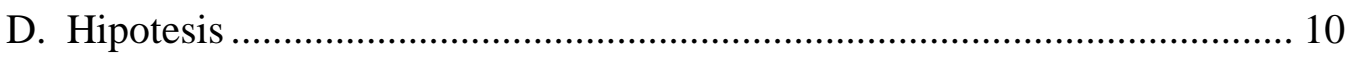

BAB III METODE PENELITIAN ........................................................... 11

A. Tempat dan Waktu Penelitian.................................................................. 11

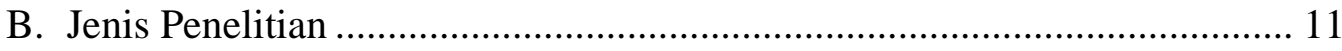

C. Populasi, Sampel, dan Sampling ......................................................... 11

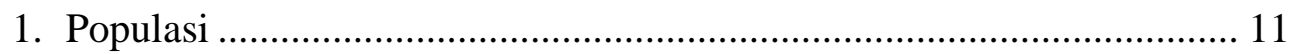

2. Sampel Penelitian ........................................................................... 12

3. Teknik Pengambilan Sampling........................................................ 12

D. Teknik Pengumpulan Data ….................................................................. 13

E. Uji Coba Instrumen Penelitian ............................................................ 14

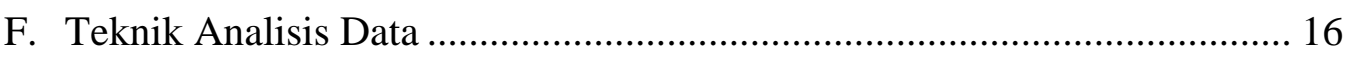

DAFTAR PUSTAKA ........................................................................................... 18 


\section{BAB I \\ PENDAHULUAN}

\section{A. Latar Belakang Masalah}

Mata pelajaran sejarah merupakan salah satu mata pelajaran yang penting dalam kurikulum 2013. Mata pelajaran sejarah dalam kurikulum 2013 berada pada kelompok wajib A untuk mata pelajaran Sejarah Indonesia, yang berarti mata pelajaran tersebut wajib ditempuh oleh seluruh peserta didik tanpa terkecuali, dan mata pelajaran sejarah terdapat juga pada mata pelajaran sejarah yang berada pada kelompok peminatan ilmu-ilmu sosial dan menjadi pelajaran lintas minat.

Menurut Seixas dalam Anis, dkk (2020) "History educators based on constructivism agree that students and teachers are provided with knowledge of the historical method known as historical thinking".

Leo Agung dalam Permana, dkk (2017) menyatakan, pembelajaran sejrah sejarah berfungsi untuk menyadarkan siswa akan adalnya proses perubahan dan berkembangnya masyarakat dalam dimensi waktu dn membangun perpektif saerta kesadaran sejarah dalam menemukan dan memahami suatu peristiwa. Artinya dalam sebuah proses pembelajaran sejarah akan terus berlangsung jika didalamnya terdapat proses penyampaian materi dari pelajaran sejarah yang ada di sekolah.

Pendidikan Sejarah memiliki fungsi dan tujuan yang tidak diragukan lagi manfaatnya bagi pembanguan sebuah bangsa. Menurut Ulhaq, dkk (2017) sebagai mata pelajaran di sekolah, sejarah tidak lagi terpisah dari nilai-nilai dan peneladanan dari tokoh-tokoh sebuah bangsa dan negara yang dharapkan akan diteruskan oleh para generasi berikutnya.

Menurut Hatta dalam (Susanto H. , 2020) pengetahuan adalah segala sesuatau yang didapat dari membaca dan pengalaman, serta ilmu pengetahuan adalah pengetahuan yang didapat dengan jalan keterangan (analisis). Jadi, pengetahuan adalah sesuatu yang bisa dibaca, dipelajari dan dialami oleh setiap orang

Hasan dalam Ulhaq, dkk (2017) mengemukakan setidaknya ada dua tujuan penting dari pendidikan sejarah, pertama sebagai media yang mampu mngembangkan potensi perseta didik untuk mengenal nilai-nilai bangsa yang terus 
bertahan, berubah dan menjadi milik bangsa masa kini. Melalui Pendidikan sejarah, peserta didik belajar mengenal bangsa dan dirinya. Tujuan yang kedua adalah sebagai wahana Pendidikan untuk mengambangkan displin ilmu sejarah.

Materi pembelajran sejarah di SMA disusun berdasrkan urutan kronologis yang dijabarkan dengan aspek-aspek tertentu sebagai materi yang tertentu yang diberikan pada semua profram studi sebagai pengetahuan Bersama. Pada mata pelajaran sejarah terdapat beberapa nilai terkandung didalamnya, nilai tersebut dapat membuat siswa memiliki sikap yang positif dalam mata pelajaran sejarah. Untuk mendapatkan sikap tersebut, maka peran guru yang dapat membuat suatu pembelajaran sejarah menjadi tidak membosankan.

Sumber belajar memiliki pengertian yang sangat luas. Sumber belajar menurut Ahmad Rohani \& Abu Ahmadi (1995: 152) dalam (Susanto \& Akmal, 2019) adalah guru dan bahan-bahan pembelajaran berupa buku bacaan atau semacamnya. Lebih lanjut, sumber belajar dapat diartikan sebagai segala daya yang dapat digunakan untuk kepentingan proses pembelajaran baik langsung maupun tidak langsung, di luar diri peserta didik yang melengkapi diri mereka pada saat pembelajaran berlangsung.

Dalam pembelajaran, faktor-faktor yang berpengaruh terhadap proses pembelajran baik secara eksternal maupun internal adalah guru, materi, pola interaksi, media, dan teknologi, situasi belajar dan system. Selain itu, pembelajaran sejarah masih dianggap sebagai pelajaran hapalan karena pembelajran sejarang dianggap sebagai pembelajaran rangkaian angka tahun dan urutan peristiwa yang harus diingat kemudian diungkap kembali saat memnjawa soal-soal ujian. Dengan begitu guru dituntut untuk memberikan inovasi baru agar dapat meningkatkan prestasi peserta didiknya.

Ada salah satu bentuk untuk meningkatkan prestasi belajar yaitu dengan memberikan sebuah motivasi belajar kepada peserta didik. Dengan adanya motivasi belajar yang diberikan guru kepada peserta didik harapannya dapat meningkatkan prestasi belajara peserta didiknya.

Salah satu faktor yang paling penting dalam tujuan Pendidikan adalah bagaimana proses belajar itu dilakukan. Sedangkan salah satu faktor penting untuk 
efektifitas pembelajaran adalah faktor evaluasi, baik terhadap proses pembelajaran berlangsung maupun hasil pembelajaran. Evaluasi dapat mendorong guru untuk meningkatkan kualitas proses pembelajran serta mendorong sekolah untuk meningkatkan fasilitas dan kualitas menajemen sekolah.

Evaluasi adalah sebuah mekanisme yang sangat penting untuk bisa menilai progresivitas pembelajaran yang telas dilakukan. Evaluasi ini akan menjadi bahan yang sangat signifikan untnuk bisa melakukan langkah-langkah perbaikan di masa mendatang pada saat suatu program akan dimulai kembali. Karena hal ini merupakan sesuatu yang sangat penting, evaluasi juga merupakan bagian dari Undang-Undang Sistem Pendidikan Nasional dan juga Standar Nasional Pendidikan (Haryanto, 2020).

Peningkatan kualitas pembelajaran di sekolah dipengaruhi banyak faktor. Faktor tersebut bisa dilihat dari: pendidik (guru), peserta didik, sarana dan prasarana, lingkungan, dan manajemennya.(Mutiani, Abbas, Syaharuddin, \& Susanto)

Menurut Fathurahman dalam (Susanto, Irmawati, Akmal, \& Abbas, 2021) terdapat beberapa komponen penting yang membuat suati kegiatan disebut pembelajran, yakni (1) adanya pendidik dan peserta didik, (2) adanya tujuan, (3) metode belajar, dan (5) media belajar.

Dalam hal ini, sebuah pembelajaran dibutuhkan guru yang tidak hanya mampu mengajar dengan baik tetapi juga mampu melakaukan evaluasi dengan baik, kegiatan evaluasi merupakan bagian dari kegiatan pembelajaran yang perlu dioptimalkan. Evaluasi tidak hanya bertumpu pada penilaian hasil belajar saja, tetapi juga perlu penilaian terhadap inpu, output maupun kualitas prosess pembelajaran itu sendiri.

Evalusi pembelajaran atau penilaian hasil belajar yang digunakan oleh guru di sekolah beraneka ragam, seperti tes seleksi, tes normative, tes sumatif, pre-test, post-test, dan lain sebagainya. Secara hakikatnya, evaluasi merupakan tolak ukur untuk mengetahui sejauh mana keberhasilan guru dalam menyampaikan sebuah materi. Pemilihan Teknik evaluasi tergantung pada tujuan yang akan dicapai oleh seorang guru tersebut. 
Berdasarkan hal tersebut, dalam rangka mengetahui pencapaian kognitif peserta didik dalam proses pembelajaran, maka diberikan tes setiap awal dan akhir pertemuan dalam pembelajaran (pre-test dan post-test) sebagai alternatif dalam meningkatkan hasil belajar peserta didik. Hal ini juga kegiatan belajar mengajar yang diberikan guru masih difokuskan sampai dimana pelajaran diberikan bukan sampai dimana penguasan siswa terhadap bahan pembelajaran yang diberikan atau kompetensi yang dicapai.

Teknik evaluasi pre-test dan post-test merupakan bentuk evaluasi pembelajaran yang dilakukan oleh guru kepada peserta didik. Kedua teknik ini sering digunakan untuk mengukur kompetensi awal dan kompetensi akhir peserta didik. Kompetensi awal merupakan tingkat pemahaman peserta didik sebelum menerima pembelajaran, sedangkan kompetensi akhir merupakan tingkat penguasaan materi peserta didik setelah menerima pembelajaran.

Pemberian pre-test yang dilaksanakan pada awal belajar akan meningkatkan frekuensi latihan belajar yang duberikan sehingga kesiapan peserta didik terhadap pembelajaran dan tes akhir lebih baik. Dari hasil kedua tes ini dapat menjadikan umpan baik yang dapat meningkatkan motivasi peserta didik dan juga berfungsi untuk melihat sejauh mana keefektifan pengajaran dan nantinya hasil pre-test akan dibandingkan dengan hasil dari post-test sehingga diketahui apakah kegiatan pembelajaran berhasil baik atau tidak, dan diharapkan peserta didik dapat memahami dengan baik dan dapat memotivasi untuk sungguh-sungguh untuk belajar sehingga dapat meningkatkan hasi belajar peserta didik.

Dalam hal ini, guna mengetahui sejauh mana pemahaman dan penguasaan peserta didik dalam pembelajaran sejarah dan bagaimana pengaruh tes ini terhadap pencapaian kognitif peserta didik pada mata pelajaran sejarah. Berdasarkan latar belalkan ii peneliti merasa tertarik untuk meneliti mengenai "Pengaruh Teknik Evaluasi Pre-Test dan Post-Test Terhadap Pencapaian Kognitif Pembelajaran Sejarah Siswa Kelas XI SMAN 1 Martapura”.

\section{B. Identifikasi Masalah}


Berdasarkan latar belakang masalah yang dijelaskan diatas, maka peneliti mengidentifikasi permasalahan yang akan dijadikan sebuah pembahasan pada penelitian ini, yaitu pembelajaran sejarah masih dianggap sebagai pembelajaran hapalan, pemahaman dan penguasaan materi pembelajaran sejarah oleh peserta didik, penentuan teknik evaluasi yang cocok dengan pembelajaran sejarah, pengaruh teknik evaluasi terhadap pemcapaian kognitif peserta didik.

\section{Pembatasan Masalah}

Berdasarkan dari latar belakang dan identifikasi masalah di atas, maka penelitian ini dibatasi pada teknik evaluasi pre-test dan post-test terhadap pencapaian kognitif pembelajaran sejarah. Sehingga masalah yang muncul dan akan diteliti adalah "Pengaruh Teknik Evaluasi Pre-Test dan Post-Test Terhadap Pencapaian Aspek Kognitif Pembelajaran Sejarah Siswa Kelas XI SMAN 1 Martapura".

\section{Rumusan Masalah}

Berdasarkan uraian latar belakang diatas, maka rumusan masalah dalam penelitian ini, yaitu:

1. Bagaimana penerapan dari teknik evaluasi pre-test dan post-test terhadap pencapaian kognitif pembelajaran sejarah Siswa kelas XI Sosial SMAN 1 Martapura?

2. Apakah pengaruh teknik evaluasi pre-test dan post-test terhadap pencapaian kognitif pembelajaran sejarah Siswa kelas XI Sosial SMAN 1 Martapura?

\section{E. Tujuan Masalah}

Berdasarkan dari rumusan masalah diatas, maka tujuan penelitian ini adalah:

1. Untuk mengetahui bagaimana penerapan dari teknik evaluasi pre-test dan posttest terhadap pencapaian kognitif pembelajaran sejarah Siswa kelas XI Sosial SMAN 1 Martapura.

2. Untuk mengetahui pengaruh dari teknik evaluasi pre-test dan post-test terhadap pencapaian kognitif pembelajaran sejarah Siswa kelas XI Sosial SMAN 1 Martapura. 


\section{F. Manfaat Masalah}

Hasil penelitian ini diharapkan akan memberikan manfaar sebagai berikut:

1. Manfaat Praktis

Memberikan kajian dan gambaran dari teknik evaluasi pre-test dan post-test terhadap pencapaian kognitif pembelajaran sejarah Siswa kelas XI Sosial SMAN 1 Martapura. Harapan dari penelitian ini dapat memberikan sebuha pengetahuan serta referensi baru bagi guru-guru mata pelajaran sejarah. Teknik evaluasi ini diharapkan menjadi sebuah inovasi bagi guru-guru mata pelajaran sejarah agar bukan hanya pemenuhan indicator saja yang terpenuhi namun pemahaman serta penguasaan peserta didik dapat terpenuhi sehingga kualitas dalam pembelajaran sejarah akan lebih baik.

2. Manfaat Teoritis

Memperkaya kajian tentang pengaruh teknik evaluasi pre-test dan post-test terhadap pencapaian kognitif siswa 


\section{BAB II \\ KAJIAN TEORI, KERANGKA PIKIR DAN HIPOTESIS}

\section{A. Kajian Teori}

\section{Evaluasi}

Kata evaluasi berasal dari Bahasa Inggris yaitu evaluation, yang berarti penilaian. Evaluasi adalah pengukuran dan perbaikan suatu kegiatan, seperti membandingkan hasil kegiatan dan menganalisisnya. Biasanya evaluasi sering dilakukan pada suatu organisasi, ataupun komunitas tertentu seteleh melaksanaakan suatu kegiatan untuk meningkatkan kualistas dan mutu.

Evaluasi termasuk kedalam Sistem Pendidikan Nasional. Hal ini dimuat dalam Undang-Undang Republik Indonesia Nomor 20 Tahun 2003 yang menyatakan bahwa "evaluasi dilakukan dalam rangka pengedalian mutu Pendidikan secara nasional sebagai bentuk akuntibilitas penyelenggara Pendidikan kepada pihak-pihak yang berkepentingan diantaranta terhadap peserta didik, Lembaga, dan program Pendidikan”.

Dalam suatu pembelajaran, evaluasi merupakan hal yang paling penting. Karena evaluasi merupakan sebuah mekanisme yang sangat penting untuk bisa menilai progresivitas pembelajaran yang telas dilakukan. Evaluasi ini akan menjadi bahan yang sangat signifikan untnuk bisa melakukan langkah-langkah perbaikan di masa mendatang pada saat suatu program akan dimulai kembali. Karena hal ini merupakan sesuatu yang sangat penting, evaluasi juga merupakan bagian dari Undang-Undang Sistem Pendidikan Nasional dan juga Standar Nasional Pendidikan (Haryanto, 2020)

Dalam setiap kegiatan evaluasi langkah yang harus diperhatikan adalah tujuan evaluasi. Penentuan tujuan evaluasi ini sangat bergantung dengan jenis evaluasi yang akan digunakan. Tujuan dari evaluasi pembelajaran adalah untuk mengetahu keefektifan dan efiensi dalam system pembelajaran, baik menyangkut tentang tujuan, materi, metode, media, sumber belajar, lingkungan, maupun system penilaian itu sendiri. 
Evaluasi dalam pembelajaran tidak lepas dengan Namanya tes. Tes adalah suatu alat yang berisi serangkaian tugas yang harus dikerjakan atau soal-soal yang harus dijawab oleh peserta didik untuk mengukur suatu aspek perilaku tertentu.fungsi tes adalah sebagai alat ukur. Dalam tes prestasi belajara, aspek perilaku yan hendak diukur adalah tingkat kemampuan peserta didik dalam menguasaan meteri pelajran yang telah disampaikan. (Arifin, 2012)

\section{Pre-Test dan Post-Test}

Pre-Test dan Post-Test adalah bentuk evaluasi pembelajaran yang dilakukan oleh furu kepada peserta didik. Kedua bentuk evaluasi ini digunakan untuk mengukur kompetensi awal dan komptensi akhir dari peserta didik. Kompetensi awal merupakan tingkat pemahaman peserta didik sebelum menerima pembelajran, sedangakan kompetesi akhir merupakan tingkat penguasaan meteri peserta didik setelah menerima pembelajaran.

Secara sederhana Pre-Test adalah sebuah tes yang dlakukan oleh guru kepada peserta didik sebelum memulai pembelajaran. Tujuan dilakukan tes ini adalah untuk mengetahui kemampuan awal peserta didik terkait materi apa yang akan disampaikan oleh guru. Dengan begitu guru dapat menentukan model dan metode apa yang akan diterapkan dalam pembelajaran jika guru sudah mengetahui kamempuan awal tersebut.

Soal biasanya mengacu pada tujuan pembelajaran yang akan dicapai. Bnetuk soal dapa berupa pilihan ganda, isian singkat, atau uraian.

Post-Test merupakan test yang diselengarakan setelah selei pelaksanaan kegiatan pebelajaran, untuk mengtahui sampai mana peserta didik mengusai materi yang sudah diajarkan.

\section{Aspek Kognitif}

Aspek kognitif merupakan kemampuan yang mencakup kegiata mental (otak) artinya kemampuan yang mendukung segala upaya yang menyangkut aktivitas otak untuk mengembangkan kemampuan rasional (akal). Dalam ranah ini terdiri dari 6 aspek yaitu pengetahuan, pemahaman, penerapan, analisis, sintensis, dan penilaian. 
Aspek ini berorientasi pada kemampuan berpikir yang menyangkut kemampuan intelektual dari mengingat, sampai pada kemampuan memecahkan masalah. untuk memecahkan masalah ini, tentu peserta didik dituntunt untuk bisa dan masir menghubungkan dan menggabungkan beberaoa metode, gagasan, ide, ataupun prosedur yang telah dipelajari untuk memecahkan masalah tersebut. Dengan demikian aspek ini bisa deisebut sebagai subtaksaonomi yang mengungkapkan tentang kegiatan mental yang sering berawal dari tingkat pengetahuan sampai yang paling tinggi yaitu evaluasi.

\section{B. Penelitian yang Relevan}

1. Penelitian yang dilakuakan oleh Widi Wulandari Universitas Negeri Yogyakarta, dengan judul Pengaruh Pemberian Pre-Test dan Post-Tesr Dalam Setiap Kegiatan Pembelajaran Terhadap Prestasi Belajar Matematika Siswa Kelas X MAN III Yogyakarta”.

2. Penelitian yang dilakukan oleh Nurul Hikmah Universitas Negeri Makassar, dengan judul "Peras Post Test terhadap Motivasi Belajar Siswa pada Mata Pelajaran Sosiologi di SMA Negeri 11 Makassar"

\section{Kerangka Pikir}

Pada hakikatnya evaluasi merupakan salah komponen penting dan tahap yang harus ditempus oleh guru untuk mengtahui keefektifan dalam sebuah pembelajaran. Hasil yang diperoleh dapat dijadikan feedback bagi guru untuk memperbaiki dan menyempurnakan profram dan kegiatan belajara yang akan mendatang.

Dalam suatu kegiatan pembelajaran, pemberian Pre-Test yang dimaksukan adalah untuk mengetahui pemahaman peserta didik terhadap materi yang akan diberikan terlebih dahulu. Dengan begitu guru dapat menentukan model dan metode apa yang akan diterapkan dalam pembelajaran. Sedangkan evaluasi Post-Test dilakasanakan setelah proses pembelajaran dengan tujuan untuk mengetahui sampai mana penguasaan peserta didik dalam pembelajaran.

Kerangka pikir tentang pembelajaran Sejarah dengan menggunakan teknik evaluasi Pre-Test dan Post-Test dapat digambarkan sebagai berikut. 


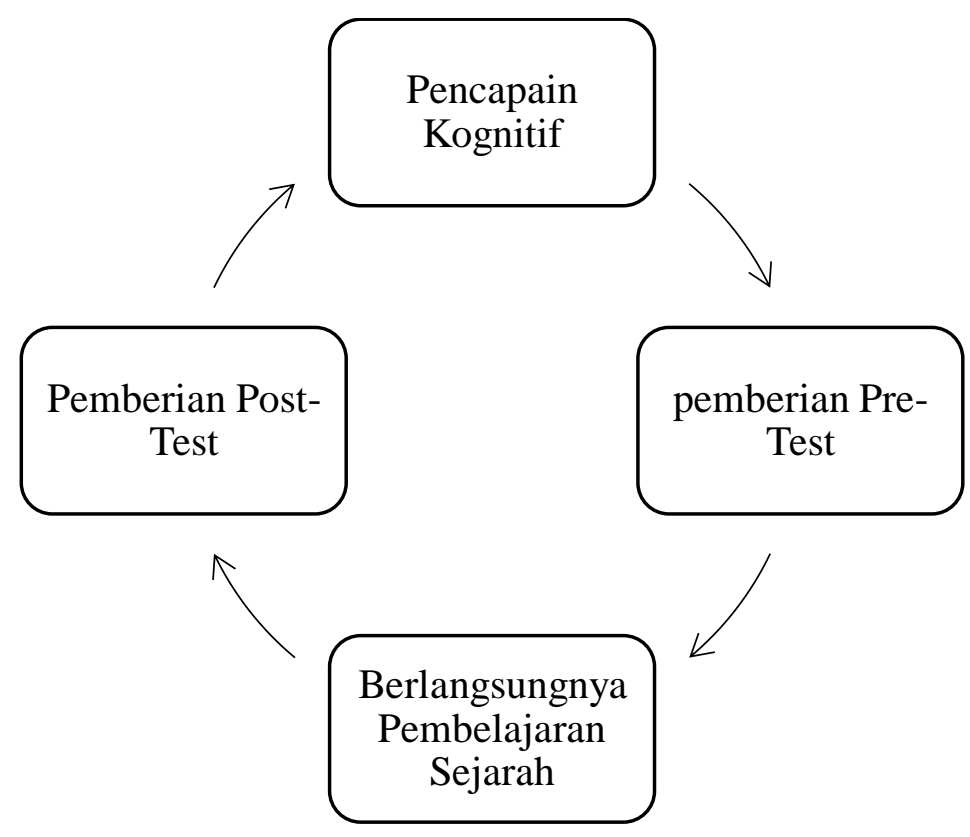

\section{Hipotesis}

Hipotesis adalah dugaan atau jawaban sementara oleh peneliti. Dalam hal ini peneliti memiliki hipotesis sebagai berikut:

"Penggunaan teknik evaluasi Pre-Test dan Post-Test dapat meningkatkan pencapaian kognitif Siswa kelas XI Sosial SMAN 1 Martapura” 


\section{BAB III \\ METODE PENELITIAN}

\section{A. Tempat dan Waktu Penelitian}

Tempat penelitian ini dilakukan pada Kelas XI Sosial di SMAN 1 Martapura yang beralamat di Jalan Jend. A. Yani No. 59 A, Kel Keraton, Kec. Martapura, Kab. Banjar, Kalimantan Selatan. Penelitian ini dilaksanakan menyesuaikan jam mata pelajaran sejarah.

\section{B. Jenis Penelitian}

Dalam penelitian kuantitatif pendekatan yang digunakan adalah pendekatan empirisme positivisme, yang melihat bahwa kebenaran berada dalam fakta-fakta yang dapat dibuktikan atau diuji secara empiris Penelitian ini menggunakan pendekatan kuantitatif yang merupakan metode penelitian untuk menjelaskan fenomena dengan menggunakan data-data numerik, kemudian dianalisis yang umumnya menggunakan statistik. Sedangkan jenis penelitian ini menggunakan model eksperimen yang mana kegunaannya adalah untuk meneyelidiki hubungan sebab akibat antara kondisi yang dimanipulasi dan keluaran yang diukur.

Jenis penelitian eksperimen yang digunakan adalah True Experiment yang sebenarnya merupakan rancangan yang paling kuat dalam menentukan pengaruh suatu variabel bebas terhadap variabel terikat.

\section{Populasi, Sampel, dan Sampling}

\section{Populasi}

Populasi adalah wilayah generalisasi yang terdiri atas objek/subjek uang memiliki kuantitas dan karateristik tertentu yang ditetapkan oleh peneliti untuk dipelajari dan kemudia ditarik kesimpulannya. Populasi adalah wilayah generalisasi dari hasil penelitian. Untuk melakukan penelitian kita harus mempunyai objek. Objek penelitian adalah sesuatu yang akan menjadi bahan perhatian penelitian kita, yang biasanya dalam penelitian Pendidikan berupa peserta didik, guru, kepala 
sekolah, orang tua peserta didik, dan semua elemen penda Pendidikan yang menghasilkan karakteristik-karakteristik atau sifat yang menjadi perhatian peneliti.

Menurut Sugiyono (2010) Populasi adalah wilayah generalisasi yang terdiri atas objek atau subjek yang mempunyai kualitas dan karajteristik tertentu yang ditetapkan oleh peneliti untuk dipelajari dan kemudian ditari kesimpulannya.

Jadi berdasarkan hal tersebut populasi dalam penelitian ini adalah seluruh siswa kelas XI Sosial 1 yang berjumlah 35 orang dan siswa kelas XI Sosial 2 yang berjumlah 31 orang di SMAN 1 Martapura.

\section{Sampel Penelitian}

Sampel penelitian kualitatif adalah cara yang memaksimalkan keluasan dan jarak rentang informasi yang diperoleh. Sampel tidak diambil dengan memperhitungkan jumlahnya tetapi lebih memperhitungkan pemilihan sumber informasi yang bertujuan untuk mendapatkan data yang lebih lengkap dan representatif. Sampel dalam penelitian kualitatif lebih bersifat mewakili informasinya daripada populasinya.

Penelitian dengan menggunakan teknik sampel lebih menguntungkan diibanding dengan menggunakan populasi saja. Oleh karena itu pertimbanganpertimbangan itu perlu diperhatikan oleh peneliti agar dalam pelaksanaan pencarian informasinya nanti dapat menghasilkan informasi yang representatif sehingga penelitiannya dapat dikategorikan penelitian yang valid (Hardani, dkk: 2020)

Berdasarkan penjelasan tersebut dalam penelitian ini jumlah sampe yang digunakan sebanyak 66 orang siswa dari kelas XI Sosial 1 dan XI Sosial 2 SMAN 1 Martapura.

\section{Teknik Sampling}

Teknik pengambilan sampling pada penelitian ini dilakukan secara Purposive Sampling. Purposive Sampling adalah teknik teknik penentuan sampel dengan pertimbangan tertentu. Pemilihan sekelompok subjek dalam purposive sampling, didasarkan atas ciri-ciri tertentu yang dipandang mempunyai sangkut paut yang erat dengan ciri-ciri populasi yang sudah diketahui sebelumnya. Maka dengan kata lain, 
unit sampel yang dihubungi disesuaikan dengan kriteria-kriteria tertentu yang diterapkan berdasarkan tujuan penelitian atau permasalahan penelitian.

\section{Teknik Pengumpulan Data}

Seorang peneliti membutuhkan bannyak alat atau teknik pengumpulan data dalam melakukan penelitian. Tes merupakan alat pengukuran dan oanduanbagi peneliti dalam pengumpulan dan evaluasi data Alat dapat bervariasi dalam kompleksitas, interpretasi, desain dan administrasi. Setiap alat cocok untuk pengumpulan jenis informasi tertentu, sehingga harus dipilih agar memberikan data yang di cari untuk menguji hipotesis (Hardani \& dkk, 2020).

Berkaitan dengan cara-cara yang ditempuh dalam rangka mendapatkan data dan informasi yang diperlukan, maka peneliti menggunakan beberapa metode pengumpulan data.

1. Observasi

Untuk mengetahui keadaan objek secara langsung, keadaan sekolah, kondisi siswa, lokasi sekolah, serta kegiatan belajar mengajar di SMAN 1 Martapura maka peneliti melakukan observasi dengan cara melihat langsung kegiatan dan fenomena seperti kejenuhan siswa ketika pembelajaran berlangsung.

Peneliti melakukan wawancara terhadap guru dan Siswa SMAN 1 Martapura. 2. Tes

Menurut Sudaryono (2016), tes sebagai instrument pengumpulan data adalah serangkaian pertanyaan atau latihan yang digunakan untuk mengukur keterampilan pengetahuan, intelegensi, kemampuan, atau bakat yang dimiliki oleh individu atau kelompok. Secara umum tes dapat diartikan sebagai alat yang digunakan untuk mengukur pengetahuan dan penguasaan objek ukur terhadap seperangkap konten dan materi tertentu.

Dalam hal ini, peneliti akan melakukan tes terhadap siswa kelas XI Sosial SMAN 1 Martapura.

3. Dokumentasi

Metode dokumentasi digunakan untuk mencari dan megumpulkan data serta informasi tertulis yang berhubungan dengan permasalahan penelitian. Dalam 
penelitihan ini metode dokumentasi digunakan untuk mengumpulkan data yang berkaitan dengan aspek kajian yang telah dirumuskan, meliputi daftar kelas dan daftar siswa.

\section{E. Uji Coba Instrumen Penelitian}

Instrumen penelitian yang telah disusun diuji coba terlebuh dahulu untuk mengetahui kesahihan dan kehandalan melalui prosedur:

\section{Uji Validitas}

Validitas berasal dari kata validity yang mempunyai arti sejauh mana ketetapan dan kecermatan suatu alat ukur dalam melakukan fungsi ukurannya. Selain itu validitas adalah suatu ukuran yang menunjukan bahwa variabel yang di ukur memang benar-benar variabel yang hendak di teliti oleh peneliti.

Adapun perhitungan validitas menggunakan kolerasi produk momen adalah sebagai berikut.

$\begin{aligned} \mathrm{rxy}=\quad & N \sum X Y-\left(\sum X\right)\left(\sum Y\right) \\ & \sqrt{ } N \sum X^{2}-\left(\sum X\right)^{2} \sqrt{ } N \sum Y^{2}-\left(\sum Y\right)^{2}\end{aligned}$

Keterangan:

rxy: koefisien korelasi Product Moment

$\sum$ Y2: jumlah kuadrat dari skor total

$\sum X$ : jumlah harga dan skor butir

$\sum \mathrm{X} 2$ : jumlah kuadrat dari skor butir

$\sum Y$ : jumlah harga dan stor total

$\mathrm{N}$ : jumlah responden

$\sum X Y$ : jumlah perkalian antara skor butir

Angka korelasi yang diperoleh harus dibandingkan dengan angka tabel korelasi $r$, apabila $r_{\text {hitung }}>r_{\text {tabel }}$ maka butir soal dikatakan valid. Sedangkan apabila rhitung $<$ rtabel maka butir soal dikatakan tidak valid. Peneliti menggunakan aplikasi pengolah data SPSS versi 16 untuk membantu dalam mengolah data.

\section{Uji Reliabilitas}

Reliabilitas menurut reliabilitas menunjukan sejauh mana hasil pengukuran dengan alat tersebut dapat di percaya. Hasil pengukuran harus reliabel dalam artian 
harus memiliki tingkat konsistensi dan kemantapan. Reliabilitas adalah konsistensi dari serangkaian pengukuran atau serangkaian alat ukur. Hal tersebut bisa pengukuran dari alat ukur yang sama. Dalam penelitian ini untuk uji reliabilitas dengan menggunakan metode Alpha Cronbach's diukur berdasarkan skala Alpha Cronbach's 0 sampai 1.

Berikut adalah rumus Alpha (Cronbach's):

$r^{i}=\frac{k 1-\sum s i^{2}}{k-1 . s t^{2}}$

\section{Uji Daya Beda}

Menurut Sudjino (2009), daya pembeda soal adalah kemampuan suatu soal untuk membedakan antara siswa pandai (berkemampuan tinggi) dengan siswa yang kurang pandai (berkemampuan rendah). Bagi suatu soal yang dapat dijawab dengan benar oleh siswa pandai maupun siswa kurang pandai, maka soal itu tidak baik karena tidak mempunyai daya pembeda. Demikian pula jika semua siswa baik pandai maupun kurang pandai tidak dapat menjawab dengan benar. Soal yang baik adalah soal yang dapat diajawab benar oleh siswa yang pandai saja.

Indeks daya pembeda dapat diukur dengan menggunakan rumus sebagai berikut:

$$
D P=P_{A}-P_{B}
$$

Keterangan:

D : Driscriminatory power (angka indeks deskriminasi item)

$\mathrm{P}_{\mathrm{A}}$ : Proporsi Peserta didik kelompok atas yang dapat menjawab dengan betul buti item yang bersangkutan. $\mathrm{P}_{\mathrm{A}}$ ini diperoleh dari rumus:

$$
P_{A}=\frac{B_{A}}{J_{A}}
$$

Keterangan:

$\mathrm{B}_{\mathrm{A}}$ : banyaknya peserta didik kelompok ataas yang dapat menjawa dengan benar butir item yang bersangkutan.

$\mathrm{J}_{\mathrm{A}}$ : jumlah peserta didik yang termasuk dalam kelompok atas.

$\mathrm{P}_{\mathrm{B}}$ : Proporsi peserta didik atas yang dapat menjawab dengan benar item yang bersangkutan. $\mathrm{P}_{\mathrm{B}}$ ini dapat diperoleh dengan rumus: 


$$
P_{B}=\frac{B_{B}}{J_{B}}
$$

Keterangan:

$\mathrm{B}_{\mathrm{B}}$ : Banyaknya peserta didik kelompok bawah yang dapat menjawab dengan benar butir item yang bersangkutan.

$\mathrm{J}_{\mathrm{B}}$ : Jumlah peserta didik yang termasuk dalam kelompok bawah

\section{Uji Indeks Kesukaran}

Menurut Sudjino (2009), Butir-butir item tes hasil belajar dapat dinyatakan sebagai butir-butir item yang baik, apabila butir-butir tersebut tidak terlalu sukaratau tidak terlalu mudah dengan kata lain tingkat kesukarannya adalah sedang atau cukup. Jadi butir-butit tes belajar akan bermutu jika diketahui tingkat kesukaran yang dimiliki masing-masing butir soal.

Indeks kesukaran dapat diperoleh dengan menggunakan rumus yang dikemukaan oleh Du Bois, yaitu:

$$
P=\frac{B}{J S}
$$

Keterangan:

$\mathrm{P}$ : proporsi (indeks kesukaran)

B : jumlah peserta yang menjawab soal tes dengan benar

JS : jumlah seluruh peserta didik peserta tes

\section{F. Teknik Analisis Data}

Teknik analisis data adalah metode dalam memproses data menjadi informasi. Saat melakukan suatu penelitian, kita perlu menganalisis data agar data tersebut mudah dipahami. Analisis data juga diperlukan agar kita mendapatkan solusi atas permasalahan penelitian yang tengah dikerjakan.

Dalam penelitian ini menggunakan dua metode analisis data, yaitu analisis deskriftif dan analisis inferensial. Analisis deskriftif dilakukan dengan penyajian data melalui table distribusi frekuesi hologram, rata-rata, simpangan baku. Sedangakan analisis inferensial digunakan pada pengujian hipotesis statistic dan diolah dengan teknok analisis data. 


\section{DAFTAR PUSTAKA}

Anis, M. Z., Putro, H. P., Susanto, H., \& Hastuti, K. P. (2020). Historical Thingkin Model in Archieve Cognitive Dimension of Indonesia History Learning. palArch's Journal of Archaeology of Egypt/Egyptology, 17 (7), 7894-7906.

Arifin, Z. (2012). Evaluasi Pembelajaran. Jakarta: Direktorat Jenderal Pendidikan Islam Kementrian Agama.

Hardani, \& dkk. (2020). Metode Penelitian Kualitatif \& Kuantitatif. Yogyakarta: Pustaka Ilmu.

Haryanto. (2020). Evaluasi Pembelajaran (Konsep dan Manajemen). Yogyakarta: UNY Press.

Mutiani, M., Abbas, E. W., Syaharuddin, S., \& Susanto, H. (n.d.). Membangun Komunitas Belajar Melalui Lesson Study Model Transcript Based Learning Analysis (TBLA) dalam Pembelajaran Sejarah. Historia. Jurnal Pendidik dan Peneliti Sejarah, 3 (2), 113-122.

Permana, N., Nuriah, T., \& Umasih. (2017). Pengaruh Metode Pembelajaran dan Kesadaran Sejarah Pada Mata Pelajaran Sejarah Terhadap Hasil Belajar Sejarah Siswa di SMA Negeri 1 Muara Bungo. Jurnal Pendidikan Sejarah, $6(2), 1-8$.

Ratnawulan, E., \& Rusdiana, H. (2014). Evaluasi Pembelajaran: Dengan Pendfrkata 2013. Bandung: Pustaka Setia.

Sudaryono. (2016). Metode Penelitian Pendidikan. Jakarta: Kencana.

Sudijono, A. (2009). Pengantar Evaluasi Pendidikan. Jakarta: Raja Grafindo Persada.

Sugiyono. (2010). Metode Penelitian Kuantitatif Kulaitatif dan R\&D. Bandung: Penerbit ALFABETA.

Susanto, H. (2020). Profesi Keguruan. Banjarmasin: FKIP ULM.

Susanto, H., \& Akmal, H. (2019). Media Pembelajaran Sejarah Era Teknologi Informasi (Konsep Dasar, Pronsip Aplikatif, dan Perancangannya). Banjarmasin: FKIP ULM. 
Susanto, H., Irmawati, I., Akmal, H., \& Abbas, E. W. (2021). Media Film Dokumenter Masuknya Islam Ke Nusantara dan Pengaruhnya Terhadap Keterampilan Berpikir Kritis Siswa. HISTORIA: Jurnal Program Studi Pendidikan Sejarah, 9(1).

Ulhaq, Z., Nuriah, T., \& Winarsih, M. (2017). Pembelajaran Sejarah Berbasi Kurikulum 2013 di SMA Kotamadya Jakarta Timur. Jurnal Pendidikan, 6, $1-12$.

Undang-Undang Nomor 20 Tahun 2003 tentang Sistem Pendidikan Nasional. (2003). Jakarta: Depdiknas.

Widyoko, E. P. (2009). Evaluasi Program Pembelajaran. Yogyakarta: Pustaka Pelajar, 1-16. 